\title{
Adaptation of the domestic market of fruits and baccas to terms of Agreement on free trade zone with EU
}

\section{Salo,}

\section{Ph.D. Institute of Horticulture, NAAS}

The purpose. To show features of development of the domestic market of fruits and baccas in conditions of formation of free trade zone and to predict its parameters for near perspective. Methods. As the basis of searching they used methodical data on actual problems of development of agrarian sector of economy and market, as well as methodical rules of prediction of the market of fruits and baccas in Ukraine. Results. Structure, trends, and cost of export-import deliveries of fruits and baccas, features of customs-tariff regulation in conditions of adaptation to demands of the Agreement on FTZ with EU and the level of provision of population with these products are analyzed. Conclusions. With formation of FTZ it is supposed to 2020 increase export-import deliveries of fruits and baccas. Export will mainly be formed by apples and walnuts, import - by citrus and bananas. According to calculations to 2020 they expect increase of consumption level of fruits and baccas up to $75 \mathrm{~kg}$ for a person a year.

Key words: market, fruits, baccas, free trade zone, customs tariffs, export, import, consumption.

Ratification of the Supreme Council of Ukraine and the European Parliament on 16 September 2014 Ukraine Association Agreement with the European Union (EU) is the defining event not only towards changes in policy, and, above all, in the formation of economic stability and development of foreign trade activity. It is not the most important part is the economic agreement, concerning the creation of a deep and comprehensive free trade area (DCFTA) after a series of reforms aimed at European model of development. Only in the schedule of commitments to bring Ukrainian legislation in line with EU standards in agriculture for 10 years should harmonize regulations 44 [1].

Against the background of what has been said is relevant and timely issue of determining the impact of these reforms on the development of industrial markets, including fruits and berries market and prospects of its development in the near future.

Economic research in the field of horticulture, as well as the domestic market of fruits and berries carried L. Symyrenko, P. Shitt, V. Yurchushun, D. Chukhno, A. Shestopal, A. Shumeyko, A. Ermakov, I. Salo, V. Rulyev, G. Satina, T. Markina, L. Kostiuk and others. However, the question remains unresolved the operation and development of the fruits and berries in the new economic conditions, such as changing the legislative framework in connection with the formation of the DCFTA, particularly on customs and tariff regulation, geography fruit and berries product sales due to the loss of the eastern partner in trade, inflation devaluation processes like.

The purpose is to reveal the peculiarities of the development of the inland fruit and small fruit market under the conditions of the trade zone formation and to predict the market parameters for the nearest future.

Methods. The ground for the studies was the methodological basis for the researches on the actual problems of the development of the agrarian sector of economy and market, as well as methodical aspects of fruits and berries market forecasting in Ukraine [2, 3].

Results. The domestic market of fruits and berries is characterized by almost stable level of total supply and low demand expansion (table. 1). Most of fruit and berries production for 2010-2014 (average $83 \%$ in 1989 ths. t) produced households. However, the size of the market they formed only $27 \%$ (411 ths. t). As fruits and berries are used primarily for their own consumption (60-65\%), and meets the needs of the population, based on established norms of consumption of $82 \mathrm{~kg}$ per person per year, only $40 \%$. 
1. Main indicators of the domestic market of fruits and berries

\begin{tabular}{|c|c|c|c|c|c|c|c|}
\hline \multirow[b]{2}{*}{ Performance } & \multicolumn{6}{|c|}{ Years } & \multirow[b]{2}{*}{$\begin{array}{l}\text { Index in } \\
2014 \text { to } \\
2010\end{array}$} \\
\hline & 2010 & 2011 & 2012 & 2013 & 2014 & $\begin{array}{l}\text { in it for } \\
\text { inter 2010- } \\
2014\end{array}$ & \\
\hline Total offer, ths. $t$ & 3880 & 4040 & 4149 & 4452 & 3981 & 4101 & 1,03 \\
\hline $\begin{array}{l}\text { The level of consumption per } \\
\text { person per year, } \mathrm{kg}\end{array}$ & 47,2 & 52,4 & 54,1 & 60,2 & 58,1 & 54 & 1,23 \\
\hline Production, ths. $t$, incl.: & 1746 & 1896 & 2009 & 2295 & 1999 & 1989 & 1,14 \\
\hline households & 1460 & 1597 & 1640 & 1851 & 1667 & 1643 & 1,14 \\
\hline agricultural enterprises & 287 & 300 & 369 & 444 & 332 & 346 & 1,16 \\
\hline Market capacity, ths. $\mathrm{t}$, incl.: & 1356 & 1479 & 1570 & 1710 & 1373 & 1498 & 1,01 \\
\hline households & 365 & 399 & 410 & 463 & 417 & 411 & 1,14 \\
\hline agricultural enterprises & 231 & 230 & 284 & 342 & 233 & 264 & 1,01 \\
\hline
\end{tabular}

Source: calculated according to State Statistics Service of Ukraine, FAO and the results of the author $[4,5]$.

From 1 November 2014 in our state made provisional application of the Agreement Establishing the DCFTA before the entry into force. Its requirements aimed at the gradual abolition of customs tariffs, dutyfree access within quotas the agricultural market of the EU, harmonization of domestic laws, regulations, standards and regulations with European. It should be noted that the EU has introduced a regime for Ukraine autonomous trade preferences - unilateral abolition of import duties relating to $83.4 \%$ of agricultural goods and food products, including fruits and berries imported from the European Union our republic. Its validity expires on 1 January 2016 [6]. Given this species is necessary to determine the structure of exports and imports of fruits and berries, geography and current sales in the future, especially the customs and tariff regulation, and establish a possible consumption to the changing quantitative and cost indicators of foreign trade.

On average for 2010-2014 fruit and berries exports of goods greater proportion (46\%, 37.2 ths. $t$ ) accounted for pome fruit, mainly apples (98.9\%) and nuts (46.9\%, 37.8 ths. t), $99.9 \%$ of the last Greek (table. 2). It should be noted that the consignment for export apples quite formed agricultural enterprises. However, farms are the main producers of walnuts (in $201499.7 \%$ or 102.4 ths. $t$ ). Intermediaries buy them form the party of export, usually as a raw material for further processing. In the future, small farms cannot be integrated into the global and European market. They cannot form a large-scale party product offering fruit or berries, their products are uncompetitive on standards, prices, quality, and no marketing and logistics activities.

It should be noted that in 2014 exports of fruits and berries decreased compared to 2010 by 2.7 times (to 54.1 ths. $t$ ). The main reasons for this are increasing demands for quality products, suspension of public funding of $1.5 \%$ of the first collection, insufficient fruit-bearing plantations laying areas, low level of industrial production fruit and berries products. Overall value of its exports in the specified year amounted to 1.135 billion grn., including walnuts $-91.2(1035 \mathrm{mln})$, apple $-5.6 \%(64 \mathrm{mln})$. This respectively 1.6 and 2.2 times more than in the previous year, indicating that the progress from inflation-devaluation processes (the dollar against the UAH in 2013 amounted to 7.99 grn., and in $2014-11$ 9, which is 1.5 times more) [7]. The price of imported apples grown in 2014 compared to 2013 by $1.2-3.2 \mathrm{grn}$. $/ \mathrm{kg}(0.27$ dollars. USA), and the walnuts 1.7 - $33.3 \mathrm{grn} . / \mathrm{kg}$ (2.8 dollars. USA). 
2. Export-import supplies of fruits and berries Ukraine

\begin{tabular}{|c|c|c|c|c|c|c|c|c|}
\hline \multirow[b]{2}{*}{ Production } & \multicolumn{6}{|l|}{ Years } & \multirow[b]{2}{*}{$\begin{array}{l}\text { Stru- } \\
\text { cture, } \\
\%\end{array}$} & \multirow[b]{2}{*}{$\begin{array}{l}\text { Index } \\
2014 \\
\text { to } \\
2010\end{array}$} \\
\hline & 2010 & 2011 & 2012 & 2013 & 2014 & $\begin{array}{l}\text { in it for } \\
\text { inter } \\
2010- \\
2014\end{array}$ & & \\
\hline \multicolumn{9}{|l|}{ Exports, ths. $t$} \\
\hline Nuts & 39,5 & 38,9 & 48,3 & 31,4 & 31,1 & 37,8 & 46,9 & 0,5 \\
\hline Bananas & 0,9 & 0,8 & 0,3 & 0,0 & 0,0 & 0,4 & 0,5 & 0,0 \\
\hline Dates, pineapples & 0,0 & 0,0 & 0,0 & 0,0 & 0,0 & 0,0 & 0,0 & 0,1 \\
\hline Citrus & 0,1 & 0,0 & 0,0 & 0,8 & 0,0 & 0,2 & 0,2 & 0,1 \\
\hline Apples, pears, quince & 99 & 36,6 & 19,3 & 11,1 & 20,2 & 37,2 & 46,1 & 0,3 \\
\hline $\begin{array}{l}\text { Apricot, vyshni, } \\
\text { chereshni, peaches, } \\
\text { plums and thorns }\end{array}$ & 4,9 & 5,5 & 3,7 & 4,7 & 2,2 & 4,2 & 5,2 & 1,2 \\
\hline Berries & 1,1 & 0,8 & 1,1 & 0,6 & 0,6 & 0,8 & 1,0 & 0,7 \\
\hline $\begin{array}{l}\text { Total fresh fruits and } \\
\text { berries }\end{array}$ & 145,5 & 82,6 & 72,8 & 48,7 & 54,1 & 80,7 & 100,0 & 1,3 \\
\hline \multicolumn{9}{|l|}{ Import, ths. $t$} \\
\hline Nuts & 7,3 & 8,9 & 9,3 & 10,2 & 6,5 & 8,4 & 1,0 & 0,5 \\
\hline Bananas & 214,8 & 247,8 & 242,6 & 265,6 & 215,1 & 237,2 & 27,4 & 0,9 \\
\hline Dates, pineapples & 12,4 & 14,4 & 17,8 & 17,7 & 10,8 & 14,6 & 1,7 & 1,3 \\
\hline Citrus & 363,4 & 413,4 & 382,8 & 443,5 & 328,1 & 386,2 & 44,6 & 1,1 \\
\hline Apples, pears, quince & 207,1 & 109,5 & 100,8 & 60,3 & 51,8 & 105,9 & 12,2 & 0,5 \\
\hline $\begin{array}{l}\text { Apricot, vyshni, } \\
\text { chereshni, peaches, } \\
\text { plums and thorns }\end{array}$ & 43,0 & 46,5 & 84,4 & 42,4 & 48,2 & 52,9 & 6,1 & 1,8 \\
\hline Berries & 54,2 & 61,1 & 71,8 & 74,1 & 41,3 & 60,5 & 7,0 & 0,9 \\
\hline $\begin{array}{l}\text { Total fresh fruits and } \\
\text { berries }\end{array}$ & 902,2 & 901,6 & 909,5 & 913,8 & 701,8 & 865,8 & 100,0 & 1,0 \\
\hline
\end{tabular}

Source: Calculated according to the FAO [5].

Objectively necessary imports (citrus fruits and bananas) to the average for 2010-2014. is 623.4 ths. $t$, which is $72 \%$ of total imports of fruits and berries. Its value was $7.1 \mathrm{mln}$ grn., or $70 \%$ of all imports.

Geographic structure of sales of fruits and berries virtually unchanged. The main buyers remains: apples and strawberries Russia - in 2014, respectively 97 and 79\% (and 19.1 ths. tand $199.8 \mathrm{t}$ ), walnuts - Romania, France, Iraq, Iran, Turkey - 51\% (15 9 ths. t). The share of exports of domestic fruits and berries to the EU is $40 \%$ ( 36.7 ths. t). Obviously, one of the leaders on the Ukrainian zakuptsi fruit and berries products is Russia. After the introduction of its embargo on fruits and vegetables in October 2014 it shipped to the Russian market through the Crimea. Given the events that have developed in eastern Ukraine, and the economic situation in general there is an urgent need to diversify external sales channels in order to prevent economic risks in the future.

The main suppliers of imported fruits and berries on the domestic market in recent years were mainly Europe and Asia. For example, in 2014 were allocated among importers: apples - Poland $(85 \%$ or 40.1 ths. t), citrus - Turkey, Egypt (64\% or 209 ths.), Peaches and nectarines - Spain, Greece ( $88 \%$ or 37 ths.), bananas - Ecuador ( $92 \%$ or 198 ths.), nuts, coconut, cashew, Brazil - Indonesia, Vietnam (81\% or 2.5 ths.), other types of — Iran, Turkey, United States, Georgia (98\% or 3.3 ths.), strawberries - Greece 
( $68 \%$ or $289 t)$. The share of EU countries that supply fruit and berries products on the domestic market of Ukraine, $23 \%$ (174 ths. t).

According to the agreement has been obliged since its entry into force to change the average current import tariff rate on agricultural production, 9.24 to $6.77 \%$. An FTA between Ukraine and the EU will gradually - over 10 years. 11-year average rate of duty is reduced to $1.38 \%$ [8].

Today the import duty on importation of fruits and berries into Ukraine is carried out according to the Customs Code of the rates approved by the Law of Ukraine "On Customs Tariff of Ukraine", which entered into force on 1 January 2014 in accordance with Art. 3. By this current was the Law of Ukraine "On Amendments to the Law of Ukraine" On Customs Tariff of Ukraine» №676-17 from 17.12.2008 y. whereby import tariffs on fruits and berries decreased after Ukraine's accession to the WTO. New tariffs for them in accordance with current legislation in 2014 did not change (table. 3).

For example, the tariff on imported apples from 1 December to 31 March $17.12 .2008 \mathrm{y}$. of $5 \%$ of the supply, and from 1 April to 30 November - 0.5 euro per $1 \mathrm{~kg}$ (ad valorem rate - 225-415\%), which during the 2001-2007 biennium greatly limited the importation of fruits. Thus, during the specified years, the bulk of imported apples (80-85\%) goes to the domestic market in the period from December to March, when import tariffs amounted to $5 \%$. It is clear that the introduction of 2008 of the new import tariffs in force for apples today ( $0 \%$ from 1 December to 31 March and $10 \%$ from 1 April to 30 November) created favorable terms of trade for importers while worsening the competitive position of domestic enterprises in the market gardening of fruits and berries.

3. Tariffs for the main types of fruit and berries in Ukraine, $\%$

\begin{tabular}{|l|l|l|l|}
\hline \multirow{2}{*}{ Production } & \multicolumn{2}{|l|}{ Full customs duties, \% } \\
\cline { 2 - 4 } & to $17.12 .2008 \mathrm{y}$. & to $01.01 .2014 \mathrm{y}$. & current \\
\hline Walnuts & 10 & 10 & 10 \\
\hline Dates, figs, pineapples, avocados & 4 & 3 & 3 \\
\hline Bananas & 3 & 0 & 0 \\
\hline Oranges, tangerines, lemons & 3 & 0 & 0 \\
\hline Apples & \multicolumn{3}{|l|}{} \\
\hline - from December 1 to 31 March & 5 & 0 & 0 \\
\hline - from 1 April to 30 November & 0,55 euro per $1 \mathrm{~kg}$ & 10 & 10 \\
\hline Pears & \multicolumn{2}{|l|}{} \\
\hline - from December 1 to 31March & 5 & 5 & 5 \\
\hline - from 1 April to 30 November & 0,55 euro per $1 \mathrm{~kg}$ & 10 & 10 \\
\hline Quince & 10 & 10 & 10 \\
\hline Apricots, cherries, plums, blackthorn & 0,55 euro per $1 \mathrm{~kg}$ & 5 & 5 \\
\hline Peaches & 0,55 euro per $1 \mathrm{~kg}$ & 5 & 5 \\
\hline Nectarines & 10 & 5 & 5 \\
\hline Strawberry & 20 & 17 & 17 \\
\hline $\begin{array}{l}\text { - from 1 January to 30 April and from } \\
\text { 1 August to 31 December }\end{array}$ & 0,65 euro per $1 \mathrm{~kg}$ & - & - \\
\hline Raspberry & 0,65 euro per $1 \mathrm{~kg}$ & 20 & 20 \\
\hline Currants & 20 & 20 & 20 \\
\hline
\end{tabular}

Source: Law of Ukraine "On Customs Tariff of Ukraine".

It is expected that with increasing scale domestic production of fruit exports in 2020 will be around 0.2 mln $t$ and will be formed mainly by apples and walnuts. [9] Location fruit and berries product sales gradually change in favor of Western Europe. In particular, the apples are in high demand in Germany, the UK, Spain, who are members of the EU $[5,10,11]$.

In 2020, the market of fruits and berries expected increase in imports by 1.8 times compared with 2014 - to $1.4 \mathrm{mln}$ t. Due offer total imports formed by $30-35 \%$, with those due to high demand, zero tariff 
rate import consist mainly of fruits objectively necessary imports. Deliveries from importers pome, stone fruits and berries virtually no change since Ukraine noted high potential of growing all kinds.

The cost of exports in 2020 could be up to 3.7 , and imports to 18.2 billion grn. That trade balance will improve in favor of exports as in quantitative terms, and for the value, but still remain negative - imports exports exceed $1.2 \mathrm{mln} \mathrm{t}$ and 14.5 billion grn.

As a result of these changes is forecast in 2020 is expected to increase consumption of fruits and berries to $75 \mathrm{~kg}$ per person per year, higher than the 1.3 times in 2014. This level corresponds to the norm of $82 \mathrm{~kg}$ at $91 \%$. The expansion will take place primarily through apples -1.3 times $(28 \mathrm{~kg}$ per person per year), citrus fruits and bananas -2.2 times $(28 \mathrm{~kg})(\mathrm{fig}$.$) .$

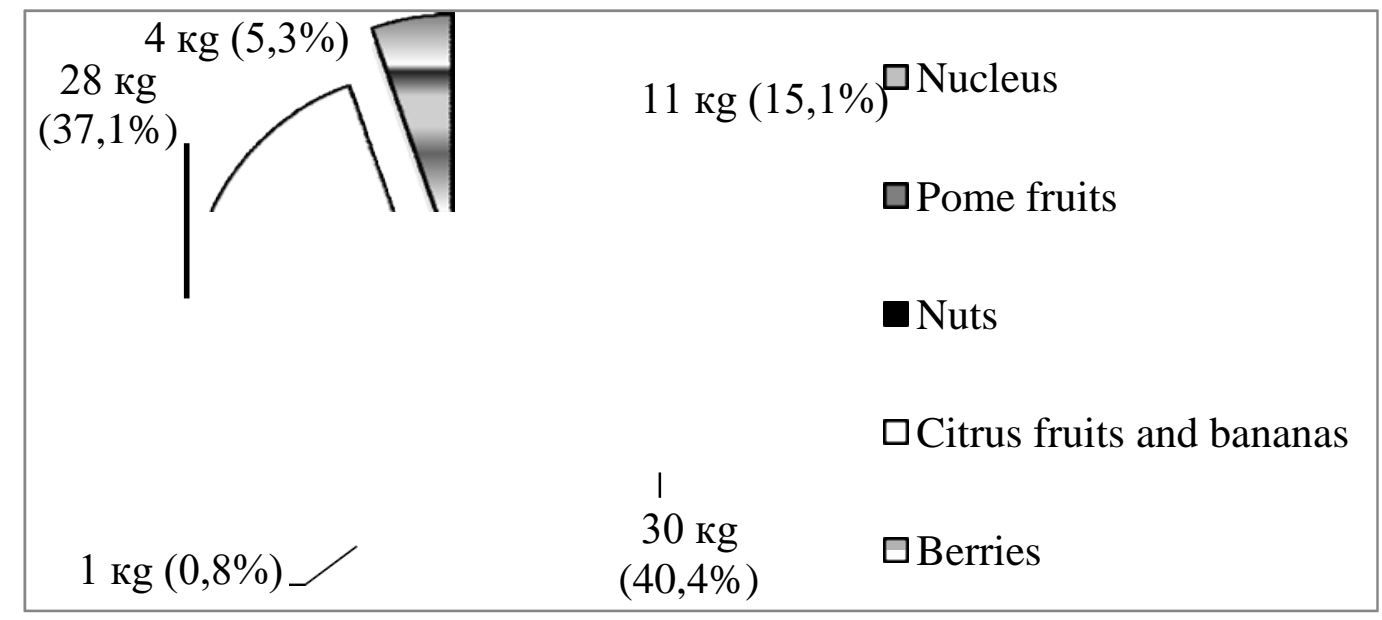

Fig. Forecast of consumption of fruits and berries in Ukraine in 2020, $\mathrm{kg}, \%$ per person per year Source: author formed.

In addition, it should be noted that there destrukturyzatsiya between the level and rate of consumption. For example, the second of these indicators for pome fruits is $57.5 \mathrm{~kg}$ with $30 \mathrm{~kg}$ of the first level, and the rate of imported fruits $3 \mathrm{~kg}$ only at the level of consumption of citrus fruits and bananas 28 . In our view, given the increasing demand for imported products and changes in foreign trade Policy should be revised consumption rates upwards. After all of these standards and the appropriate level of prices depending on the types of fruits and berries formed fraction of the cost of the consumer basket of the population.

The low rate of increase in consumer goods caused fruit and berries insufficient effective demand of the population. As of August 2014 the level of wages in dollar terms Ukraine second only to Moldova, the income of the average Ukrainian is 15 times smaller than the American [4, 12]. If the September 2013 average wage amounted to 408 , then in February 2015 to 128 dollars. USA devaluation, which is 3 times less and despite the significant increase in inflation.

\section{Conclusions}

Since forming in the future DCFTA 2020 expected expansion of export-import supplies of fruits and berries. Exports formed mainly at the expense of apples and walnuts, and import - citrus and bananas. Location marketing is gradually changing in favor of countries in Western Europe, given that the share purchase local fruits and berries is quite high $-40 \%$, which is almost 2 times the share of imports in the domestic market. Tariffs for the main types of fruits and berries remained unchanged since 2009. Thus a significant impact customs-tariff instruments to the general supply in the domestic market by imported products were found. With the expansion of domestic production and import of fruits and berries in 2020 expected to increase consumption to $75 \mathrm{~kg}$ per person per year. 


\section{References}

1. The economic component of the Association Agreement between Ukraine and the EU: implications for business, the public and public administration; ed. I. Burakovsky and V. Movchan. - Institute for Economic Research and Policy Consulting, K .: 2014. - 140 p.

2. Kvasha S. Methodological basis social decision-making in agricultural policy / S. Kvasha // Economics APC. -2013 . - № 8. - P. 12-21.

3. Salo I. Methodical provisions forecasting market conditions fruits and berries in Ukraine / I. Salo. K: WC NUBiP, 2009. $-60 \mathrm{p}$.

4. Statistical Yearbook of Ukraine for 2014 / [way. A. Osaulenko; ed. by vol. A. Ostapchuk]. - K., Consultant, 2015. - $560 \mathrm{p}$.

5. FAOSTAT - FAO Statistics Division 2015 [electronic resource]. — Access: http://faostat.fao.org/

6. Creation of free trade zone between Ukraine and the EU [electronic resource]: Portal - a single Web portal by the executive power of Ukraine. - Access: http://www.kmu.gov.ua/control/publish/article? art_id $=244830558$

7. The official hryvnia exchange rate against foreign currencies (period average) [electronic resource]. - Access: www.bank.gov.ua/ files / Exchange_r.xls.

8. Zinchuk T. Problems of Adaptation of the agricultural sector the terms of a free trade zone UkraineEU / T. Zinchuk // Economics APC. - 2015. — №5. - P. 79-87.

9. Salo I. The development of the fruit market in Ukraine [monograph] / I. Salo. —K.: NNC IAE, 2013. $394 \mathrm{p}$.

10. Burmester C. Earnings garden and viticulture / C. Burmester. - Bonn: BMVEL, 2004. - $126 \mathrm{p}$.

11. Earnings horticulture and viticulture 2012 (data analysis). - Bonn: BMVEL, 2012. - $171 \mathrm{p}$.

12. Shpychak $A$. Economic-organizational relationships inconsistencies in grocery chains in conditions from inflation-devaluation processes: directions settlement / A. Shpychak // Economics APC. - 2015. №6. - P. 85-94. 